JPPKMI 1 (1) (2020)
JURNAL PENELITIAN DAN PENGEMBANGAN
KESEHATAN MASYARAKAT INDONESIA
Jttps://journal.unnes.ac.id/sju/index.php/jppkmi

\title{
Kajian Mitigasi Bencana Tanah Longsor Berdasarkan Permendagri No 33 Tahun 2006
}

\author{
Lugas Yan Prastowo ${ }^{1}$, Anik Setyo Wahyuningsih ${ }^{1}$ \\ ${ }^{1}$ Jurusan Ilmu Kesehatan Masyarakat, Fakultas Ilmu Keolahragaan, Univesitas Negeri Semarang, Indonesia
}

\begin{abstract}
Abstrak
Pendahuluan: Terdapat 12 ancaman bencana di Indonesia yang digolongkan dalam bencana geologi, hiderometeorologi, dan antropogenik. Tanah longsor merupakan bencana yang paling sering terjadi di Provinsi Jawa Tengah yaitu sebanyak 1007 kejadian yang terjadi pada kurun waktu 2015 sampai 2018. Kabupaten Banjarnegara merupakan daerah dengan risiko dan jumlah bencana tanah longsor paling tinggi di Provinsi Jawa Tengah. Mitigasi bencana merupakan upaya penanggulangan bencana yang paling diutamakan oleh pemerintah dengan panduan pelaksanaan mitigasi bencana yaitu Permendagri No. 33 Tahun 2006. Tujuan dari penelitian ini adalah mengetahui gambaran pelaksanaan mitigasi bencana tanah longsor di Kabupaten Banjarnegara. Metode: Jenis dan desain penelitian ini adalah deskriptif kualitatif. Teknik pengumpulan data menggunakan observasi partisipatif yang bersifat pasif, wawancara semi terstruktur, dan hasil akan diuji keabsahan datanya menggunakan teknik triangulasi data. Penelitian ini dilaksanakan bulan Agustus-September 2019. Hasil: Hasil penelitian menunjukan pelaksanaan mitigasi bencana tanah longsor berdasarkan Permendagri No. 33 Tahun 2006 di Kabupaten Banjarnegara secara keseluruhan adalah sebanyak 29 kriteria terpenuhi dan 1 kriteria yang tidak terpenuhi. Penutup: Simpulannya yaitu persentase sebesar $96 \%$ dan masuk dalam kriteria penilaian memuaskan.
\end{abstract}

Alamat korespondensi:

Gedung F5 Lantai 2 FIK Unnes

Kampus Sekaran, Gunungpati, Semarang, 50229 


\section{PENDAHULUAN}

Pada tahun 2015 hingga 2018 terjadi peningkatan tren kejadian bencana di Indonesia yaitu pada tahun 2015 sebanyak 1694 kejadian, tahun 2016 sebanyak 2306 kejadian, tahun 2017 sebanyak 2862, dan tahun 2018 sebanyak 2572 kejadian. Dimana bencana dengan kejadian yang paling banyak adalah kejadian bencana banjir, puting beliung dan tanah longsor dan Provinsi yang memiliki tingkat kejadian bencana tertinggi adalah Jawa Tengah. Tanah longsor merupakan bencana yang paling banyak terjadi di Jawa Tengah, dalam 4 tahun terakhir yaitu tahun 2015 sebanyak 167 kejadian, tahun 2016 sebanyak 250 kejadian, tahun 2017 sebanyak 487 kejadian, dan tahun 2018 sebanyak 150 kejadian. Dengan total keseluruhan sebanyak 1007 kejadian dari 2393 jumlah keseluruhan kejadian bencana. Jika dipersentasekan maka jumlah kejadian bencana tanah longsor mencapai $42 \%$ dari jumlah keseluruhan bencana yang ada di Jawa Tengah. Hal tersebut menunjukan bahwa bencana tanah longsor merupakan bencana yang paling banyak terjadi. Banjarnegara adalah kabupaten yang memiliki kawasan pegunungan dengan risiko tanah longsor cukup tinggi. Selain itu Kabupaten Banjarnegara merupakan daerah dengan jumlah kejadian bencana tanah longsor paling tinggi dibandingkan dengan daerah yang lainnya. Terjadi kejadian bencana tanah longsor sebanyak 86 kejadian dalam rentang waktu 2015 sampai 2018. Terdapat beberapa lembaga yang ikut serta dalam penanggulangan bencana khususnya dalam mitigasi bencana, diantaranya adalah Dinas Pekerjaan Umum \& perumahan rakyat, Dinas Lingkungan Hidup, Dinas Tata Kota, dan Badan Penanggulangan Bencana Daerah (Herlianto, 2015).

Wilayah Kabupaten Banjarnegara memiliki luas $1.070 \mathrm{Km}^{2}$ terdiri dari 20 Kecamatan menurut kajian geologi $70 \%$ dari luas Kabupaten Banjarnegara atau 17 Kecamatan merupakan daerah rawan longsor meliputi Kecamatan Wanayasa (64,41 ha),
Pagedongan (43,78 ha), Banjarnegara (38,84 ha), Bawang (18,65 ha), Kalibening (1,21 ha), Karangkobar (3,58 ha), Pandanarum (21,34 ha), Susukan (4,03 ha), dan Mandiraja (0,30 ha). Faktor alami seperti kemiringan lereng yang tinggi, curah hujan tinggi, kondisi geologi merupakan faktor yang berpengaruh di wilayah ini. Potensi kerentanan longsor pada wilayah ini semakin meningkat dengan adanya infrastruktur yaitu bangunan akibat kepadatan penduduk pada wilayah-wilayah yang rentan terhadap longsor (Susanti, 2017).

Bencana bisa terjadi melalui suatu proses yang panjang atau situasi tertentu dalam waktu yang sangat cepat tanpa adanya tanda-tanda. Penanggulangan bencana bukan hanya pada saat terjadinya bencana dan pasca bencana namun jauh sebelum terjadinya bencana tindakan pencegahan dan mitigasi sudah dimulai, dimana hal ini bertujuan untuk meminimalisir dampak yang ditimbulkan baik jiwa ataupun harta. penyelenggaraan penanggulangan bencana merupakan serangkaian upaya yang meliputi penetapan kebijakan pembangunan yang berisiko timbulnya bencana, kegiatan pencegahan bencana, tanggap darurat, dan rehabilitasi. Artinya bahwa mitigasi merupakan serangkaian upaya untuk mengurangi risiko bencana, baik melalui pembangunan fisik maupun penyadaran dan peningkatan kemampuan menghadapi ancaman bencana (Sunarti, 2014).

Mitigasi bencana merupakan sebuah tuntutan bagi daerah/kabupaten yang memiliki tingkat kerawanan bencana rendah hingga tingkat kerawanan yang tinggi. Konsep mitigasi bencana sebagai tahap awal dalam manajemen bencana memiliki keterkaitan dengan proses kebijakan publik dimana perlu menentukan posisi mitigasi bencana untuk dijadikan keputusan dalam kebijakan publik. Dengan mempertimbangkan aspek mitigasi bencana berarti mitigasi bencana juga sebagai proses kebijakan evaluatif yang menyebabkan perumusan ulang kebijakan (Faturohman, 2018). 
Mitigasi bencana adalah serangkaian upaya untuk mengurangi risiko bencana, baik melalui pembangunan fisik maupun penyadaran dan peningkatan kemampuan menghadapi ancaman bencana. Mitigasi bencana adalah upaya untuk mencegah atau mengurangi dampak yang ditimbulkan suatu bencana. Dari batasan ini sangat jelas bahwa mitigasi bersifat pencegahan sebelum kejadian (Anies, 2017).

Kegiatan mitigasi bencana hendaknya merupakan yang bersifat rutin dan berkelanjutan (sustainable disaster mitigation). Kegiatan mitigasi seharusnya sudah dilakukan dalam periode jauh-jauh hari seebelum kejadian bencana, yang seringkali datang lebih cepat dari waktuwaktu yang diperkirakan, dan bahkan memiliki intensitas yang lebih besar dari yang diperkirakan semula. Selain itu pemerintah hendaknya juga aktif memberikan berbagai arahan yang tepat dan berkesinambungan dalam memghadapi peristiwa bencana atau dengan kata lain bisa beradaptasi dengan resiko potensi bencana alam yang ada. Dalam konteks pengurangan risiko bencana, mitigasi bencana juga dipahami sebagai upaya meningkatkan kapasitas masyarakat yang berada di kawasan rawan bencana untuk menghilangkan atau mengurangi akibat dari ancaman dan tingkat bencana (Desfandi, 2014).

Terdapat penelitian sebelumnya mengenai mitigasi bencana tanah longsor di Kabupaten Banjarnegara yang dilakukan oleh Rahman tahun 2015, dengan hasil bahwa mitigasi bencana di Banjarnegara masih berfokus pada mitigasi struktural dan non struktural. Untuk mitigasi struktural, berupa pembuatan infrastruktur sebagai pendorong minimalisasi dampak dan penggunaan pendekatan teknologi dengan gejala yang diamati berupa penyusunan data base daerah potensi bencana dan pembuatan early warning system. Kemudian untuk mitigasi non struktural, berupa pengelolaan tata ruang dan pelatihan guna meningkatkan kapasitas masyarakat. Dengan sumber penelitian hanya dilakukan pada satu instansi saja yaitu Badan Penanggulangan Bencana Daerah (BPBD) Kabupaten banjarnegara tanpa melakukan penelitian pada instansi lain yang berkaitan dalam upaya penanggulangan bencana khususnya mitigasi bencana (Rahman, 2015). Yang membedakan penelitian ini dengan penelitian sebelumnya adalah jumlah responden yang lebih luas, pada penelitian ini tidak hanya BPBD yang dijadikan sebagai responden melainkan juga Dinas Kesehatan (DINKES), Dinas Pekerjaan Umum Perumahan Rakyat (DPUPR), Dinas Perhubungan (DISHUB), dan Dinas Lingkungan Hidup (DLH). Selain itu peneliti menggunakan Permendagri No 33 Tahun 2006 dalam mengkaji pelaksanaan mitigasi bencana tanah longsor di Kabupaten Banjarnegara.

Penelitian ini bertujuan untuk mengetahui gambaran pelaksanaan mitigasi bencana tanah longsor yang dilaksanakan di Kabupaten Banjarnegara menggunakan panduan Permendagri No 33 Tahun 2006 tentang panduan umum mitigasi bencana. Dalam setiap upaya mitigasi bencana perlu adanya panduan dalam setiap pelaksanaanya, diantaranya perlu adanya dokumen berupa pedoman pelaksanaan, standar pelaksanaan dan prosedur pelaksanaan yang dikeluarkan oleh instansi yang bersangkutan sesuai dengan bidang tugas unit masing-masing. Selain itu dalam pelaksanaan juga harus berdasarkan peraturan perundangan terkait, dalam hal ini peraturan tentang mitigasi bencana yang terdapat didalam Permendagri No. 33 tahun 2006 tentang panduan umum mitigasi bencana dimana terdapat banyak indikator pencapaian mitigasi bencana yang harus dicapai.

\section{METODE}

Jenis desain penelitian ini adalah penelitian kualitatif deskriptif. Penelitian ini dilakukan pada bulan Agustus sampai dengan September 2019 di Kabupaten Banjarnegara. Dengan sumber informasi dari penelitian menggunakan sumber informasi primer dan sumber informasi sekunder dengan teknik purposive sampling. Data primer dalam penelitian ini diperoleh dengan wawancara secara langsung dengan Instansi yang terlibat dalam 
penanggulangan bencana di daerah Kabupaten Banjarnegara khususnya pada bagian mitigasi bencana, yaitu: Kepala Seksi Pencegahan dan Kesiapsiagaan Badan Penanggulangan Bencana Daerah, Kepala Dinas Pekerjaan Umum dan Perumahan Rakyat, Kepala Dinas Lingkungan Hidup dan Kehutanan, Kepala Dinas Kesehatan, dan Kepala Dinas Perhubungan. Data sekunder berasal dari majalah ilmiah, peraturan perundang-undangan, sumber dari arsip, dokumen pribadi dan dokumen resmi lainnya.

Teknik pengambilan data dilakukan menggunakan tiga cara, yaitu dengan observasi partisipatif yang bersifat pasif, wawancara semi struktural, dan studi dokumentasi. Dalam penelitian ini, observasi dilakukan dengan bantuan lembar observasi yang telah dirancang sistematis dan gambar dokumentasi sehingga lebih memudahkan peneliti dalam observasi lapangan. Wawancara dilakukan dengan menggunakan lembar panduan wawancara yang telah disusun sebelumnya dan dalam studi dokumentasi dibantu dengan lembar studi dokumentasi. Dalam penelitian ini pemeriksaan keabsahan data dilakukan dengan cara membandingkan dan mengecek data dari hasil wawancara dengan hasil observasi serta studi dokumentasi.

Analisis data yaitu data reduction, data display, dan conclusion. Terdapat rumus statistik distribusi frekuensi untuk menghitung tingkat kesesuaian poin-poin dengan standar yang ada. Skala untuk tingkat kesesuaian terdiri dari ada dan tidak ada. Jawaban ada dan tidak ada dikalikan $100 \%$ dan dibagikan dengan total poin yaitu 30 poin. Sehingga akan didapatkan persentase tingkat kesesuaian pada setiap indikatornya. Rumus statistik tersebut adalah sebagai berikut:

$\%$ kesesuaian poin $=\frac{\text { Tingkat kesesuaian } \times 100 \%}{\text { Total poin }}$

Kesimpulan akhir diambil dalam penelitian deskriptif melalui penyaringan yang panjang dari kesimpulan-kesimpulan dalam proses penelitian. Kesimpulan akhir dilakukan setelah proses pengambilan data diakhiri karena informasinya sudah jenuh. Berdasarkan Peraturan Menteri Ketenagakerjaan Republik Indonesia Nomor 26 Tahun 2014, hasil akhir disimpulkan menggunakan penentuan kriteria sebagai berikut: Tingkat penilaian penerapan kurang, apabila tingkat pencapaian penerapan sebesar $0-59 \%$, tingkat penilaian penerapan baik, apabila tingkat pencapaian penerapan sebesar $60-84 \%$, tingkat penilaian penerapan memuaskan, apabila tingkat pencapaian penerapan sebesar $85 \%-100 \%$.

\section{HASIL DAN PEMBAHASAN}

Dalam pelaksanaan upaya mitigasi bencana tanah longsor berdasarkan Permendagri No 33 Tahun 2006 di Kabupaten Banjarnegara, hasil persentase dari pelaksanaan masing-masing instansi dapat dilihat pada tabel 1.

Selanjutnya untuk persentase pelaksanaan mitigasi bencana berdasarkan Permendagri No. 33 Tahun 2006 di Kabupaten Banjarnegara secara keseluruhan adalah sebanyak 29 kriteria terpenuhi dan hanya ada satu kriteria yang tidak terpenuhi yaitu indikator prosedur kerjasama. Dalam pelaksanaan mitigasi bencana oleh 5 instansi terkait masingmasing mempunyai peranan yang berbeda dalam pelaksanaan mitigasi bencana. Mereka saling melengkapi satu sama lain dalam pemenuhan indikator dalam mitigasi bencana sesuai dengan tugas dan fungsi utamanya. Sehingga jika dipersentasekan maka pencapaian pelaksanaan mitigasi bencana tanah longsor di Kabupaten Banjarnegara berdasarkan indikator Permendagri No 33 tahun 2006 yang dilaksanakan oleh 5 instansi adalah sebesar $96 \%$ dan masuk dalam kriteria penilaian memuaskan. Tingkat penilaian penerapan memuaskan, apabila tingkat pencapaian penerapan sebesar $85 \%-100 \%$.

Dalam pelaksanaan mitigasi bencana tanah longsor di Kabupaten Banjarnegara, acuan yang digunakan adalah Permendagri No 33 Tahun 2006 tentang panduan umum mitigasi bencana. Dalam acuan tersebut terdapat 30 kriteria pencapaian, dan masing-masing instansi 
memiliki pencapaian yang berbeda untuk setiap poinnya. Terdapat 5 instansi terkait di

Tabel 1. Hasil Persentase Pelaksanaan di Instansi
Kabupaten Banjarnegara yang berperan dalam pelaksanaan mitigasi bencana, dalam hal

\begin{tabular}{|c|c|c|c|c|}
\hline \multirow[t]{2}{*}{ No } & \multirow[t]{2}{*}{ Instansi } & $\begin{array}{l}\text { Indikator } \\
2006\end{array}$ & gri No 33 Tahun & \multirow[t]{2}{*}{ Persentase } \\
\hline & & Tercapai & Tidak tercapai & \\
\hline 1 & BPBD & 21 & 9 & $70 \%$ \\
\hline 2 & DPUPR & 17 & 13 & $56 \%$ \\
\hline 3 & DINKES & 16 & 14 & $53 \%$ \\
\hline 4 & DISHUB & 7 & 23 & $23 \%$ \\
\hline 5 & DLH & 11 & 19 & $36 \%$ \\
\hline
\end{tabular}

kebijakan dan komitmen tiga dari lima instansi terkait yaitu BPBD, DPUPR, dan DINKES sudah mempunyai kebijakan dan komitmen mengenai penanganan bencana. Untuk DISHUB dan DLH masih belum mempunyai kebijakan dan komitmen terkhusus untuk penanganan bencana. Dikarenakan kedua instansi tersebut tidak mempunyai tugas utama dalam kebencanaan sehingga tidak mengutamakan kebijakan khusus mengenai kebencanaan. Disisi lain menurut Profil Kerjasama Kesiapsiagaan BNPB, Dishub dan DLH merupakan instansi yang mempunyai kerjasama kebencanaan dengan BNPB. Selain itu dalam suatu instansi keberadaan kebijakan dan komitmen sangatlah berperan penting. Terbukti bahwa hasil pengujian hipotesis menunjukkan bahwa komitmen organisasi berpengaruh positif terhadap kinerja karyawan, semakin tinggi komitmen organisasi maka semakin tinggi pula kinerja karyawan (Handoko, 2017).

Dalam mitigasi bencana di Kabupaten Banjarnegara, 5 instansi terkait sudah mempunyai tugas dan fungsi khusus tentang kebencanaan. Namun intensitas tugas dan fungsi dari masing-masing instansi tidak sama, melainkan berbeda satu sama lain. Dengan adanya pembagian tugas dan fungsi pada instansi atau organisasi akan bedampak baik bagi instansi itu sendiri, karena berdasarkan dengan penelitian yang telah dilakukan dapat diketahui bahwa hubungan antara pembagian kerja sudah baik maka efektifitas organisasi pun tingkatannya juga baik sesuai dengan yang diharapkan (Murti, 2015).
Di Kabupaten Banjarnegara, 5 instansi yang terkait dalam mitigasi bencana semua mempunyai acuan yang berbeda beda antara satu dengan yang lainnya. Sebagian besar acuan yang digunakan berbentuk Peraturan Bupati Kabupaten Banjarnegara dan perundangan nasional. Terkecuali untuk DINKES mempunyai (Standar Operasional Prosedur) SOP tersendiri yang dibuat berdasarkan Surat Keputusan Kepala Dinas Kesehatan. SOP tersebut dibuat khusus sebagai panduan untuk penanganan bencana, dari penanganan sebelum, saat terjadi, dan setelah bencana.

Dari pemetaan daerah rawan bencana yang dimiliki oleh BPBD dan DINKES, serta peta pemanfaatan ruang oleh DPUR. Masih terdapat 2 instansi yang belum mempunyai pemetaan kebencanaan yaitu DISHUB dan DLH. Kedua instansi tersebut memang belum terdapat upaya dalam pembuatan peta kebencanaan. Dalam pembuatan peta kebencanaan terdapat beberapa sifat peta risiko ancaman yaitu dinamis, partisipatif dan akuntabel. Dalam upaya mitigasi bencana, peta kebencanaan sangatlah penting untuk mengurangi rsiko bencana, karena sesuai dengan platform regulasi tentang penyelenggaraan bencana nasional, pada dasarnya merupakan komponen yang wajib diadakan, utamanya dalam konteks perencanaan beragam upaya untuk meminimalkan risiko bencana (Rogi, 2017).

Di Kabupaten Banjarnegara 5 instansi yang terkait dalam upaya mitigasi bencana sudah mempunyai upaya pemantauan terhadap risiko bencana tanah longsor. Jenis pemantauan yang dilakukan oleh 5 instansi berbeda satu 
sama lain menyesuaikan peranan dan tugas instansi tersebut. Untuk BPBD mempunyai upaya pemantauan yang dilakukan oleh desa tangguh bencana yang ada di masing-masing desa di Kabupaten Banjarnegara, DPUPR melakukan pengawasan secara langsung mengenai pemanfaatan lahan atau ruang yang rawan atau berisiko terjadi bencana tanah longsor, DINKES melakukan pemantauan melalui puskesmas dalam kejadian bencana yang ada pada masing-masing daerah, DISHUB melakukan pemantauan terhadap kondisi jalan dan penerangan, DLH melakukan pengawasan terhadap hutan lindung yang telah ditetapkan oleh dinas kehutanan. Semua pemantauan yang dilakukan merupakan upaya mitigasi bencana untuk mengurangi risiko bencana tanah longsor. Menurut Permendagri No 33 Tahun 2006 dengan mengetahui tingkat kerawanan secara dini, maka dapat dilakukan antisipasi jika sewaktu-waktu terjadi bencana, sehingga akan dengan mudah melakukan penyelamatan. Pemantauan di daerah vital dan strategic secara jasa dan ekonomi dilakukan di beberapa kawasan rawan bencana (Permendagri, 2006).

Kabupaten Banjarnegara terdapat 5 instansi yang terkait dalam penyebaran informasi kebencanaan, diantaranya adalah BPBD, DPUPR, DINKES, DISHUB, DLH. Untuk penyebaran informasi kebencanaan pada masing-masing instansi mempunyai cara dan media penyebarannya tersendiri, contohnya menggunakan sosial media berupa Instagram, twiter, facebook, email, whatsapp, dan website. kehadiran media dalam mewartakan bencana dan menggambarkan keterlibatannya dalam peristiwa bencana itu sendiri. Keterlibatan media dapat dilihat dari posisinya sebagai pembawa informasi dan sebagai bagian dari suatu pengoperasian manajemen informasi bencana. Dengan landasan bahwa keselamatan, keamanan dan kesehatan umat manusia adalah hal yang utama, arah dari aksi dan keterlibatan media dalam membawakan peran pra, saat dan paskabencana adalah mengabdi pada kemanusiaan dan kehidupan (Prajoto, 2013).

Di Kabupaten Banjarnegara hanya 2 instansi yang terdapat pelaksanaan sosialisasi dan penyuluhan mengenai kebencanaan, yaitu BPBD dan DPUPR. Dimana bentuk sosialisasi yang ada berupa tatap muka secara langsung (sosialisasi daerah rawan, sosialisasi desa tangguh bencana, dan sosialisasi penguatan kapasitas) dan menggunakan media berupa baliho. Untuk instansi lain yaitu DINKES, DISHUB, dan DLH terdapat sosialisasi atau penyuluhan akan tetapi tidak terkhusus untuk penanganan kebencanaan, melainkan menyesuaikan tugas utama dari masing-masing instansi. Tujuan utama sosialisasi dan penyuluhan menurut Permendagri NO 33 Tahun 2006 adalah memberikan pengetahuan terhadap masyarakat dan Pemerintah Daerah mengenai hidup harmonis dengan alam di daerah bencana, apa yang perlu dilakukan dan dihindarkan di daerah rawan bencana, dan mengetahui cara menyelamatkan diri jika terjadi bencana.

BPBD dan DINKES sebagai instansi yang berperan dalam hal kebencanaan telah melaksanakan dan mengadakan pelatihan berupa, pelatihan relawan, pelatihan simulai bencana, pelatihan alat kebencanaan, dan bimbingan teknis desa tangguh bencana. Kemudian untuk instansi lain yaitu DPUPR, DISHUB, dan DLH mereka masih berperan sebagai peserta pelatihan saja, khususnya pelatihan yang dilaksanakan oleh BPBD. Pendidikan dan pelatihan merupakan unsur yang sangat penting, karena akan membantu tenaga kerja dalam memperoleh efektivitas pekerjaannya (Berliana, 2019). Pelatihan kebencanaan sangatlah penting guna meningkatkan kemampuan masyarakat dalam menghadapi bencana. Penyelenggaraan pelatihan penanggulangan bencana harus mempunyai tujuan yang jelas agar masyarakat dapat memperoleh keterampilan yang sesuai dengan apa yang diharapkan.

Di Kabupaten Banjarnegara upaya peringatan dini sudah di lakukan oleh BPBD Banjarnegara, melalui pemasangan alat deteksi dini tanah longsor yang bersumber dari stakeholder lain seperti BNPB, BPBD Jawa Tengah, BMKG, LIPI, dan Badan Geologi. Dan terdapat alat yang dibuat sendiri oleh 
BPBD Bnajrnegara sebagai inovasi tentang peringatan dini. Untuk 4 instansi lain masih belum berperan dalam melaksanakan upaya peringatan dini, dikarenakan perlu biaya yang tinggi untuk membuat alat deteksi dini khususnya tanah longsor.

Instansi di Kabupaten Banjarnegara yang sudah mempunyai program peningkatan kapasitas adalah BPBD dan DINKES berupa kegiatan pelatihan terhadap sumber daya manusia yang ada. Instansi lain seperti DPUPR, DISHUB, dan DLH masih belum ada upaya peningkatan kapasitas internalnya dalam hal kebencanaan, khususnya mitigasi bencana. Pengembangan kapasitas pada umumnya diartikan sebagai peningkatan kemampuan atau kompetensi individu, kelompok dan organisasi yang mencangkup banyak komponen, sehingga didalam pengembangan kapasitas terdapat beberapa dimensi dan fokus. Dimensi dan fokus tersebut merupakan bagian proses dinamis yang berkelanjutan (Sari, 2013).

Di Kabupaten Banjarnegara yang sudah melakukan kerjasama dalam hal mitigasi bencana hanya 3 instansi saja, yaitu BPBD, DINKES, dan DLH. Untuk DPUPR dan DISHUB masih belum melakukan upaya kerjasama dalam hal kebencanaan. Sebagai negara dengan kondisi geografis yang rawan bencana alam, Indonesia dinilai masih lemah dalam koordinasi penanganan bencana alam, seperti banjir, tanah longsor, hingga erupsi gunung berapi. Hal penting yang patut mendapat perhatian adalah bahwa penanganan bencana tidak hanya dapat dilakukan oleh pemerintah saja akan tetapi juga bersinergi dengan masyarakat dan stakeholders lain yang terkait (Widodo, 2014).

Dalam upaya kerjasama dengan lembaga atau instansi lain perlu adanya prosedur dalam kerjasama. Prosedur tersebut digunakan sebagai panduan dalam melaksanakan kerjasama. Panduan tersebut dibuat dengan kesepakatan pihak-pihak yang melakukan kerjasama tersebut. Ke-5 instansi di Banjarnegara belum ada yang mempunyai prosedur kerjasama secara tertulis. Hanya berupa kerjasama secara insidental melalui pertemuan langsung dan menyesuaikan kondisi kebencanaan yang terjadi.

Di Kabupaten Banjarnegara instansi kebencanaan yang sudah mempunyai kerjasama dengan instansi lain yaitu BPBD, DPUPR, dan DINKES sudah terdapat pembagian tugasnya dalam mitigasi bencana dengan menyesuaikan tugas pokok instansi tersebut. Untuk DISHUB dan DLH masih belum mempunyai kerjasama mengenai kebencanaan sehingga belum terdapat pembagian tugas dan fungsi secara khusus tentang kebencanaan. Pembagian kerja di setiap instansi perlu diadakan karena dapat memberikan dampak positif bagi instansi terkait. Dengan adanya pembagian kerja itu pula, maka karyawan dapat memiliki kesempatan untuk mempelajari keterampilan dan keahlian pada pekerjaan tertentu yang telah menjadi wewenang dan tanggung jawab mereka. Karyawan dapat terfokus pada beberapa pekerjaan saja yang telah menjadi tugas dan tanggung jawabnya masing-masing sehingga hal tersebut dapat memudahkan karyawan dalam melaksanakan pekerjaannya, sehingga efektivitas kerja karyawan dapat tercapai dan akhirnya tujuan organisasipun tercapai (Amrita, 2011).

Dalam upaya mitigasi bencana, perlu juga adanya persiapan untuk keadaan darurat maupun pemulihan akibat bencana. Persiapan tersebut baik berupa persiapan sumber daya manusia, peralatan maupun sistem kebencanaan yang ada. Persiapan awal yang harus dilakukan dalam mempersiapkan keadaan darurat adalah sebagai berikut: pembentukan tim penanggulangan keadaan darurat, sarana dan fasilitas keadaan darurat meliputi serta mengadakan pelatihan dan lomba. Untuk instansi di banjarnegara terdapat 2 instansi yang sudah mempunyai upaya dalam mempersiapakan keadaan tanggap darurat dan pemulihan. Kedua instansi tersebut adalah BPBD dan DINKES. Upaya yang dilakukan berupa persiapan sistem dan skema kedaruratan oleh BPBD dan pembentukan tim reaksi cepat (TRC) oleh dinas Kesehatan. Untuk 3 instansi lain masih belum mempunyai upaya persiapan yang terstruktur, hanya mempersiapkan upaya 
evakuasi apabila terjadi bencana, persiapan tersebut hasil dari pelatihan yang sudah diikuti sebelumnya.

Untuk menghadapi keadaan darurat, perlu adanya persiapan terlebih dahulu. Salah satunya adalah dengan pembentukan tim tanggap darurat oleh masing-masing instansi. Dengan adanya tim tanggap darurat apabila terjadi bencana maka tim tersebut yang akan bergerak dan mengkoordinir anggota lainnya. Organisasi tanggap darurat adalah pengelompokan orang-orang serta penetapan tugas masing masing dengan tujuan terciptanya aktifitas yang berkaitan dengan kedaruratan. Sesuai dengan tujuan tersebut organisasi tanggap darurat pada bangunan gedung perkantoran sebaiknya terdiri dari unsur pengelola bangunan dan penghuni bangunan (Handayana, 2016). Instansi di Banjarnegara yang sudah mempunyai tim tanggap darurat kebencanaan adalah BPBD dan DINKES berupa tim reaksi cepat (TRC). Untuk instansi lain yaitu DPUPR, DISHUB, DLH belum mempunyai organisasi tim tanggap darurat dikarenakan kemampuan internal instansi tersebut belum mempersiapkan upaya keadaan darurat secara terperinci. Dalam memilih dan menyusun komposisi anggota TRC terdiri dari Ketua Tim, Anggota dan Petugas Administrasi.

Peralatan kebencanaan harus terorganisir dengan baik, agar dapat termonitoring dengan baik. Salah satu upaya yang dapat dilakukan adalah dengan infentarisasi peralatan. Pengamanan administrasi yang ditunjang oleh pengamanan fisik dan pengamanan hukum atas barang milik negara/daerah merupakan bagian penting dari pengelolaan barang milik negara/daerah. Kuasa pengguna barang, pengguna barang dan pengelola barang memiliki wewenang dan tangling jawab dalam menjamin keamanan barang milik negara/daerah yang erada di bawah penguasaannya dalam rangka menjamin pelaksanaar tugas pokok dan fungsi pemerintah. Instansi di Kabupaten Banjarnegara yang sudah mempunyai upaya infentarisasi peralatan adalah BPBD, DINKES, dan DSHUB. Dimana alat yang diinventarisasikan sesuai dengan tugas dan fungsi utama ke-3 instansi tersebut. Selain itu instansi tersebut memang mempunyai peralatan yang dapat digunakan dalam rangka penanganan bencana. Untuk DPUPR dan DLH tidak mempunyai infentasisasi peralatan khususnya peralatan yang digunakan untuk penanggulangan bencana. Terdapat tujuan dan manfaat dari inventarisasi peralatan. Tujuan Inventarisasi Secara umum, inventarisasi dilakukan dalam rangka usaha peyempurnaan pengurusan dan pengawasan yang efektif terhadap sarana dan prasaran yang dimiliki.

Pemodelan kinerja jaringan dalam kondisi terdegradasi difokuskan pada pengaturan rute lalu lintas daripada pergeseran moda dan pilihan tujuan atau pendekatan dengan pengaturan lalu lintas yang melibatkan pemilihan rute pengemudi, sehingga perilaku pemilihan rute dari pengemudi dalam situasi tertentu mengikuti beragam keseimbangan. Bahwa model transportasi berperan sangat penting untuk mengoptimalkan kinerja rute yang dilewati pengungsi ketika evakuasi. Jaringan jalan dengan kinerja paling optimal dapat ditetapkan sebagai rute evakuasi yang tangguh untuk menghadapi bencana di masamasa mendatang, tentunya dengan regulasi dan aturan yang jelas pada tingkat pengoperasiannya (Hardiyansah, 2016). Di Kabupaten Banjarnegara sudah melakukan pengorganisasian transportasi darurat. Untuk instansi yang berperan dalam hal ini dalah DISHUB dan DINKES. Dishub berperan dalam pengaturan lalulintas dan rute jalan untuk proses evakuasi yang paling efektif dan efisien. Kemudian untuk DINKES berperan menyediakan alat transportasi berupa ambulans yang tersedia di setiap puskesmas yang ada di masing-masing Kecamatan di Kabupaten Banjarnegara. Untuk instansi lain seperti BPBD lebih berperan dalam pengerahan relawan dan bantuan peralatan kebencanaan, DPUPR dan DLH berperan dalam pemulihan daerah akibat bencana.

Dalam pelaksanaan upaya mitigasi bencana, salah satu hal yang perlu diperhatikan adalah pada bidang kesehatan. Untuk meminimalisir dampak bidang kesehatan, perlu 
adanya koordinasi dengan instansi yang berperan dalam bidang kesehatan. Bencana alam yang disertai dengan pengungsian seringkali menimbulkan dampak terhadap kesehatan masyarakat yang menjadi korban, terlebih mereka yang termasuk dalam kelompok rentan. Permasalahan kesehatan akibat bencana beragam, termasuk meningkatnya potensi kejadian penyakit menular maupun penyakit tidak menular, permasalahan kesehatan lingkungan dan sanitasi serta kesehatan reproduksi perempuan dan pasangan. Kondisi dapat menjadi Iebih buruk antara lain dikarenakan pemberian pelayanan kesehatan pada kondisi bencana sering tidak memadai. Di Kabupaten Banjarnegara instansi yang menangani di bagian kesehatan adalah DINKES. Dinas Kesehatan sudah melakukan koordinasi dengan instansi kesehatan lainnya, terutama dengan puskesmas yang ada di masing-masing kecamatan di Banjarnegara. Dengan adanya kerjasama tersebut maka upaya kesehatan khususnya dalam hal kebencanaan dapat dilaksanakan secara merata. Kemudian apabila dari pihak puskesmas tidak memungkinkan untuk melakukan penanganan kesehatan, maka akan di rujuk ke fasilitas kesehatan yang tingkatannya lebih tinggi yaitu rumah sakit dengan melalui koordinasi terlebih dahulu.

Dalam upaya mitigasi bencana perlu adanya persiapan dalam upaya pemulihan akibat bencana. Upaya tersebut perlu dilaksanakan agar pelaksanaan pemulihan dapat berjalan secara maksimal. Instansi harus membuat prosedur rencana pemulihan keadaan darurat secara cepat mengembalikan pada kondisi yang normal dan membantu pemulihan tenaga kerja yang mengalami trauma. Segera setelah krisis ditanggulangi, rencana pemulihan bencana dilakukan jika kegiatan operasional tidak berjalan. Jika tidak, kehilangan waktu dalam pemulihan akan memakan waktu produksi instansi. Dalam mitigasi bencana terdapat beberapa upaya perencanaan pemulihan yang dilakukan oleh instansi kebencanaan yang ada di Kabupaten Banjarnegara. Empat instansi sudah mempunyai upaya perencanaan pemulihan seperti pelatihan relawan oleh $\mathrm{BPBD}$, mengikuti kegiatan JITUPASNA oleh DPUPR, Pengorganisasian peralatan kesehatan dan obatobatan oleh dinas kesehatan dan penghijauan kembali atau reboisasi oleh DLH.

Salah satu unsur penting dalam upaya mitigasi bencana adalah peranan dari masyarakat itu sendiri. Apabila peranan instansi atau pemerintahan sudah sesuai tetapi dari masyarakatnya masih belum ikut serta di dalamnya maka upaya penanganan bencana masih belum maksimal. Oleh karena itu perlu adanya penumbuhan rasa partisipatif masyarakat secara aktif agar pelaksanaan mitigasi bencana dapat berjalan dengan baik. Menurut Perka BNPB No 11 Tahun 2014 tentang peran serta masyarakat dalam penanggulangan bencana menyebutkan bahwa aspek peran serta masyarakat dalam upaya $\mathrm{PB}$ tersebut meliputi (1) Pengambilan keputusan, (2) Memberikan informasi yang benar kepada publik, (3) Pengawasan, (4) Perencanaan, (5) Impelementasi, dan (6) Pemeliharaan program kegiatan PB. Di Kabupaten Banjarnegara terdapat upaya yang dilakukan oleh BPBD guna meingkatkan partisipasi aktif dari masyarakat, yaitu berupa pembuatan desa tangguh bencana (DESTANA). Dimana masyarakat yang ada di dalam desa tangguh bencana tersebut diajarkan untuk lebih berperan aktif dalam menghadapi risiko bencana yang ada, melalui sosialisasi dan pelatihan desa tangguh bencana oleh BPBD (BNPB, 2014).

Bangunan harus dirancang dalam suatu tim dengan mengikutsertakan berbagai bidang keahlian yang relevan. Dengan demikian dapat dihasilkan konsep, strategi, kebijaksanaan perancangan bangunan yang optimal. Dan tidak ada aspek pertimbangan penting yang terlewatkan. Apabila keamanan bangunan sudah dipikirkan sejak awal dengan konsep prencanaan yang memperhatikan peranan bangunan sebagai salah satu elemen perkotaan. Hal tersebut merupakan kontribusi untuk menghindarkan dampak yang lebih luas dan berskala lingkungan kota. Pengembangan infrastruktur merupakan bagian dari upaya 
mitigasi bencana secara struktural. Pembuatan dan rekayasa infrastruktur harus dipertimbangkan dengan kajian risiko bencana yang ada. Agar pembangunan infrastruktur tersebut dapat mengurangi risiko bencana. Pembangunan infrastruktur di Kabupaten Banjarnegara dilaksanakan oleh DPUPR yang beracu pada Rancangan Pembangunan Jangka Menengah Daerah (RPJMD) Kabupaten Banjarnegara. Upaya yang sudah dilakukan dalam bidang infrastruktur berupa perbaikan jalan dan jembatan. Selain itu DLH juga ikut serta dalam bidang infrastruktur berupa program pembangunan di daerah kumuh yang disebut program KOTAKU.

Dalam keadaan risiko bencana tinggi, posisi bangunan strategis dan penting perlu diperhatikan keamanannya. Dari segi bangunan dan sumber daya manusia yang ada di dalamnya. Di Kabupaten Banjarnegara, DPUPR berperan dalam meningkatkan keamanan bangunan strategis dan penting, dengan cara pemberian izin membangun bangunan dengan mempertimbangkan risiko yang ada di lahan atau ruang yang akan digunakan. Apabila ruang atau lahan tersebut tidak aman maka DPUPR tidak akan memberikan izin membangun dan memberikan rekomendasi yang lebih aman.

Pelaksanaan mitigasi bencana terhadap daerah perumahan dan kawasan permukiman harus dilakukan, karena terdapat perundangan yang mengatur mengenai hal tersebut yaitu Peraturan Mentri Perumahan Rakyat Republik Indonesia No. 10 Tahun 2014 tentang pedoman mitigasi bencana alam bidang perumahan dan kawasan permukiman. Mitigasi bencana tanah longsor bidang perumahan dan kawasan permukiman dilakukan terhadap rumah serta prasarana, sarana dan utilitas umum meliputi membangun struktur bangunan dengan pondasi yang kuat, membangun sengkedan lahan pada wilayah yang memiliki kelerengan cukup tinggi untuk memperlandai lereng, membangun prasarana, sarana dan untilitas umum yang memadai, menempatkan konstruksi penahan tanah konvensional, memberi beban penyeimbang, memberikan jangkar untuk penguatan tanah. Pelaksanaan mitigasi bencana berdasarkan Permendagri no 33 tahun 2006 penanganan bencana meliputi 4 sektor, salah satunya adalah sektor perumahan dan fasilitas umum. Upaya yang sudah dilakukan adalah oleh DPUPR berupa perijinan dan rekomendasi terhadap pembangunan dan pemanfaatan lahan, selain itu DLH juga melakukan program yang dinamakan KOTAKU yang bertujuan untuk pengelolaan daerah kumuh di Kabupaten Banjarnegara. Program tersebut berupa pembuatan konstruksi penahan tanah di wilayah kumuh tersebut, kemudian juga berupa pembuatan sanitasi pemukiman agar dapar berjalan lancar (Permendagri, 2006).

Sekolah merupakan lembaga pendidikan formal yang dianggap efektif dalam mengubah pola pikir dan perilaku masyarakat. Diharapkan agar pemerintah Indonesia bersama instansi terkait, terus bekerja sama dalam mengimplementasikan kurikulum kebencanaan kedalam semua jenjang pendidikan, disesuaikan dengan usia dan kapasitas anak dalam menghadapi keadaan darurat (Rahma, 2018). Salah satu upaya meningkatkan kapasitas masyarakat agar lebih sadar terhadap bencana adalah melalui instansi sekolah. Dalam keamanan bencana di sekolah, BPBD Banjarnega selain melaksanakan sosialisasi dan pelatihan mengenai kebencanaan, juga melaksanakan program berupa pembuatan buku muatan lokal tentang kebencanaan, dimana buku tersebut dibuat melalui kerjasama dengan Dinas Pendidikan Kabupaten Banjarnegara dan PMI Kabupaten Banjarnegara. Sasaran pembuatan buku tersebut adalah siswa SMP (Sekolah Menengah Pertama) yang dimasukan dalam kegiatan pramuka, PMR (Palang Merah Remaja), dan Pecinta alam. Untuk materi yang terangkum dalam buku tersebut berupa dasardasar kebencanaan dan upaya pecegahan serta mitigasi bencana.

Perlu di perhatikan tentang pemanfaatan ruang atau lahan apakah sudah aman atau berisiko terhadap bencana tanah longsor. Upaya pengawasan tersebut dilakukan oleh DPUPR dalam pemanfaatan ruang atau guna lahan. Selain itu DPUPR juga memberikan 
rekomendasi pembangunan gedung sekolah agar lebih aman dan terhindar dari risiko bencana tanah longsor. Karena sekolah merupakan lembaga pendidikan formal yang dianggap efektif dalam mengubah pola pikir dan perilaku masyarakat. Pendidikan dapat membantu membentuk pengetahuan, keterampilan dan sikap anak, yang nantinya akan berperan sebagai agen peubah (agent of change) dalam masyarakat, untuk membentuk budaya masyarakat sadar bencana (Rahma, 2018). Oleh karena itu, program keamanan gedung sekolah perlu diperhatikan. Karena kegiatan pembelajaran di sekolah tidak akan berjalan dengan baik apabila keamanan gedung tidak diperhatikan.

Salah satu upaya mitigasi atau pencegahan terhadap risiko bencana adalah dengan cara membuat bangunan yang tahan terhadap risiko bencana yang ada. semua bangunan yang ada perlu adanya pengawasan dalam pembangunannya agar bangunan yang dibuat dapat memperhatikan aspek risiko yang ada, diantaranya adalah risiko bencana tanah longsor. Instansi di Kabupaten Banjarnegara yang sudah melakukan upaya tersebut adalah DPUPR khususnya dalam pemanfaatan ruang yang ada. Pengawasan terhadap bangunan sekolah terhadap risiko bencana tanah longsor sudah dilakukan oleh instansi DPUPR. Upaya yang dilakukan dengan cara memberikan ijin membangun bangunan dengan memperhatikan risiko bencana yang ada dan memberikan rekomendasi agar pembangunan atau pemanfaatan ruang yang dilakukan dapat diminimalisir risiko bencana yang ada.

Dalam upaya mitigasi bencana, perencanaan tata ruang dan tata guna lahan sangat diperlukan sebagai upaya pengelolaan pemanfaatan ruang dan lahan. Dengan adanya perencanaan tersebut maka dapat meminimalisir risiko bencana yang ada. Upaya perencana tata ruang dan guna lahan dilaksanakan dengan berbagai pertimbangan, salah satunya adalah pertimbangan kajian risiko bencana. Dalam hal ini adalah bencana tanah longsor. Di Kabupaten Banjarnegara upaya ini dilaksanakan oleh DPUPR, karena dinas tersebut mempunyai tugas utama dalam pengelolaan penggunaan lahan dan tata ruang berupa perijinan membangun bangunan dan rekomendasi pembangunan yang aman dari risiko bencana yang ada, khususnya adalah bencana yang sering terjadi di daerah Banjarnegara yaitu tanah longsor. Upaya rekomendasi terhadap pemanfaatan ruang dan tata guna lahan menjadi hal penting yang harus dilakukan, karena dengan adanya rekomendasi tersebut maka masyarakat atau badan usaha yang akan memanfaatkan lahan dapat mengetahui rekomendasi terbaik agar terhindar dari risiko bencana yang ada.

\section{PENUTUP}

Penelitian tentang Kajian Mitigasi Bencana Tanah Longsor Berdasarkan Permendagri No 33 Tahun 2006 di Kabupaten Banjarnegara dilaksanakan oleh 5 instansi terkait yaitu BPBD, DPUPR, DINKES, DISHUB, DLH. Setiap instansi mempunyai peranan dan upaya masing-masing dalam pelaksanaan mitigasi bencana menyesesuaikan dengan tugas dan fungsi utamanya serta saling melengkapi dalam pelaksanaan mitigasi bencana khususnya dalam pemenuhan kriteria Permendagri No 33 tahun 2006 tentang panduan mitigasi bencana Indikator penilaian adalah sebanyak 30 kriteria, dengan hasil 29 terpenuhi dan hanya ada satu kriteria yang tidak terpenuhi yaitu indikator prosedur kerjasama. Pencapaian pelaksanaan pada masing-masing instansi paling tinggi diperoleh oleh BPBD dengan persentase pelaksanaan sebesar $70 \%$, diikuti oleh DPUPR sebesar 56\%, DLH sebesar $36 \%$, dan untuk pencapaian pelaksanaan paling rendah ada pada DISHUB dengan persentase pencapaian sebesar $23 \%$.

Kelemahan dari penelitian ini adalah keberadaan dokumen di masing-masing instansi yang tidak terdokumentasi dengan baik, kemudian jenis bencana dan acuan yang digunakan hanya satu saja. Saran bagi peneliti selanjutnya untuk meneliti topik ini secara lebih mendalam, yaitu dapat menambah jenis bencana untuk diteliti yang memiliki risiko 
tinggi, dapat mencari indikator penilaian yang lain sebagai panduan dalam menilai variabel yang akan diteliti, dapat menggunakan metode lain dalam mengolah data yang ada hasil penelitian, dapat memperluas atau mencari tempat lain untuk diteliti dengan risiko bencana yang lebih tinggi.

\section{DAFTAR PUSTAKA}

Amrita, D. 2011. Pembagian Kerja Dalam Rangka Meningkatkan Efektivitas Kerja Karyawan. Jurnal Ekonomi, 1(1): 1-6.

Anies. 2017. Negara Sejuta Bencana. Yogyakarta: ArRuzz Media.

Berliana, R. 2019. Tinjauan Sistem Manajemen Keselamatan dan Kesehatan Kerja pada Akreditasi Rumah Sakit. HIGEIA (Journal of Public Health Research and Development), 2(3): 501-502.

BNPB. 2014. Peraturan Kepala BNPB No 11 Tahun 2014 Tentang Peran Serta Masyarakat dalam Penyelenggaraan Penanggulangan Bencana. Jakarta.

Desfandi, M. 2014. Urgensi Kurikulum Pendidikan Kebencanaan Berbasis Kearifan Lokal di Indonesia. Sosio Didaktika, 1(2): 192-198.

Faturohman, B. M. 2018. Koseptualisasi Mitigasi Bencana Melalui Prespektif Kebijakan. Jurnal Ilmu Administrasi Publik, 3(2): 133.

Handayana, M. 2016. Analisis Manajemen Pelaksanaan Pada Kesiapsiagaan Dan Tanggap Darurat Di Gedung Perkantoran X. Jurnal Kesehatan Masyarakat, 4(1): 322-331.

Handoko, T. 2017. Pentingnya Komitmen Organisasi Terhadap Kinerja Karyawan PT. Teduh Semarang. Bingkai Manajemen, 1(1): 155.
Hardiyansah. 2016. Konsep Permodelan Transportasi Untuk Evakuasi Bencana. Jurnal Transportasi, 16(3): 231-240.

Herlianto, M. 2015. Profil Sumber Daya Kesiapsiagaan Nasional Dalam Penanggulangan Bencana Tahun 2015. Jakarta: BNPB.

Murti, E. 2015. Pentingnya Komitmen Organisasi Terhadap Kinerja Karyawan PT. Teduh Semarang. Jurnal Sosial, 91-92.

Permendagri. 2006. Peraturan Mentri Dalam Negeri No 33 Tahun 2006 Tentang Panduan Umum Mitigasi Bencana. Jakarta.

Prajoto, N. 2013. Bencana, Informasi dan Keterlibatan Media. Jurnal Ilmu Komunikasi, 11(3): 287-306.

Rahma, A. 2018. Implementasi Program Pengurangan Risiko Bencana (Prb) Melalui Pendidikan Formal. Varia Pendidikan, 30(1): 1-11.

Rahman, A. Z. 2015. Kajian Mitigasi Bencana Tanah Longsor DI Kabupaten Banjarnegara. Jurnal Manajemen Dan Kebijakan Publik, 1(1): 1-14.

Rogi, O. 2017. Peta Kebencanaan: Urgensi dan Manfaatnya. Media Matrasain, 14(3): 61-76.

Sari, N. 2013. Pengembangan Kapasitas Kelembagaan Pemerintah Daerah Dalam Meningkatkan Kualitas Pelayanan Perizinan Terpadu (Studi Pada Kantor Pelayanan Dan Perizinan Terpadu Kabupaten Kediri). Jurnal Administrasi Publik (JAP), 2(4): 634-640.

Sunarti, V. 2014. Peranan Pendidikan Luar Sekolah Dalam Rangka Mitigasi Bencana. SPEKTRUM PLS, 2(2): 31-41.

Susanti. 2017. Analisis Kerentanan Tanah Longsor Sebagai Dasar Mitigasi. Jurnal Penelitian Pengelolaan Daerah Aliran Sungai, 1(1): 49-59.

Widodo, A. 2014. Manajemen Resiko Bencana Melalui Kerjasama Antar Daerah (Studi Tentang Manajemen Resiko Bencana Gunung Slamet). Permana, 6(1): 64. 